\title{
THE FIRST RECORD OF RHAMPHOMYIA (PARARHAMPHOMYIA) INTERSITA (DIPTERA: EMPIDIDAE) IN EUROPE
}

\author{
Miroslav Barták ${ }^{1}$ \& Bože KoKAN ${ }^{2}$ \\ ${ }^{1}$ Department of Zoology and Fisheries, Faculty of Agrobiology, Food and Natural Resources, Czech \\ University of Life Sciences Prague, Kamýcká 129, CZ-16500 Praha 6-Suchdol, Czech Republic (e-mail: \\ bartak@af.czu.cz) \\ ${ }^{2}$ Natural History Museum Split, Kolombatovićevo šetalište 2, 21000 Split, Croatia
}

Barták, M. \& Kokan, B.: The first record of Rhamphomyia (Pararhamphomyia) intersita (Diptera: Empididae) in Europe. Nat. Croat., Vol. 26, No. 2, 325-330, 2017, Zagreb.

A dance fly (Diptera: Empididae) Rhamphomyia (Pararhamphomyia) intersita Collin, 1960, previously known from Israel and Turkey, is recorded for the first time in Europe (Croatia). A new record is presented, with a photo of the voucher specimen. A key to the Palaearctic species of Rhamphomyia (Pararhamphomyia) with black legs, multiserial dorsocentrals and an at least partly pale setose body is provided.

Key words: Dance flies, Empidoidea, Empididae, Israel, Turkey, Croatia, distribution, identification

Barták, M. \& Kokan, B.: Prvi nalaz vrste Rhamphomyia (Pararhamphomyia) intersita (Diptera: Empididae) u Europi. Nat. Croat., Vol. 26, No. 2, 325-330, 2017, Zagreb.

Muha plesačica (Diptera: Empididae) Rhamphomyia (Pararhamphomyia) intersita Collin, 1960, prethodno poznata iz Izraela i Turske, zabilježena je po prvi puta u Europi i to u Hrvatskoj. U radu se predstavlja prvi nalaz, uz sliku dokaznog primjerka. Rad donosi i ključ za palearktičke vrste roda Rhamphomyia i podroda Pararhamphomyia s crnim nogama, multiserijskim dorzalnocentralnim setama, i barem djelomično blijedim setoznim tijelom.

Ključne riječi: muhe plesačice, Empidoidea, Empididae, Izrael, Turska, Hrvatska, rasprostranjenost, određivanje vrsta

\section{INTRODUCTION}

The genus Rhamphomyia Meigen, 1822 is one of the three megadiverse groups within the family Empididae (dance flies, dagger flies or balloon flies), together with Empis Linnaeus, 1758 and Hilara Meigen, 1822. Almost 600 species, distributed mostly in the Northern Hemisphere have been described worldwide (e.g. Yang et al., 2007; ВаRTÁK, 1982, 2007; BARTÁK et al., 2007; BARTÁK \& KubíK, 2008a, 2008b, 2008c, 2009, 2010, 2012, 2015; BАRTÁK et al., 2014; SAIGUSA, 2012), but many more await description.

Rhamphomyia intersita was described by Collin (1960) from Palestine and for a long time it was known only from the area close to the type locality (ВАRTÁк \& Кивík, 2009). Recently it was recorded from south-west Turkey (BARTÁK et al., 2014). The species was redescribed and illustrated in details by ВАRт́́к \& Киві́к (2009). A recent investigation into Diptera at a site near Split (Croatia, Dalmatia, Dinarides) revealed the presence of the species.

Most Rhamphomyia are species occurring in early spring to late summer, and only very few species occur in autumn (or winter - in subtropical climates). In Israel, $R$. intersita was found between 22 October and 17 February, in Turkey approximately at the same time (between November and March).

The aims of this paper are to present a new finding of the species $R$. intersita in a distant region and to present a valid key for distinguishing this species from other, similar, species of the huge Pararhamphomyia subgenus. 


\section{MATERIAL AND METHODS}

The material was collected by means of a Malaise trap situated in the village of Gornji Muć, located $15 \mathrm{~km}$ from the Adriatic coast in the hinterland of the city of Split. The trap was placed on a sunny hill slope named Grudina at $500 \mathrm{~m}$ a.s.l., in an orchard, at position $43^{\circ} 41^{\prime} 27^{\prime \prime} \mathrm{N}, 16^{\circ} 29^{\prime} 44^{\prime \prime} \mathrm{E}$ on the southeast foothills of Svilaja Mountain (Fig. 1).
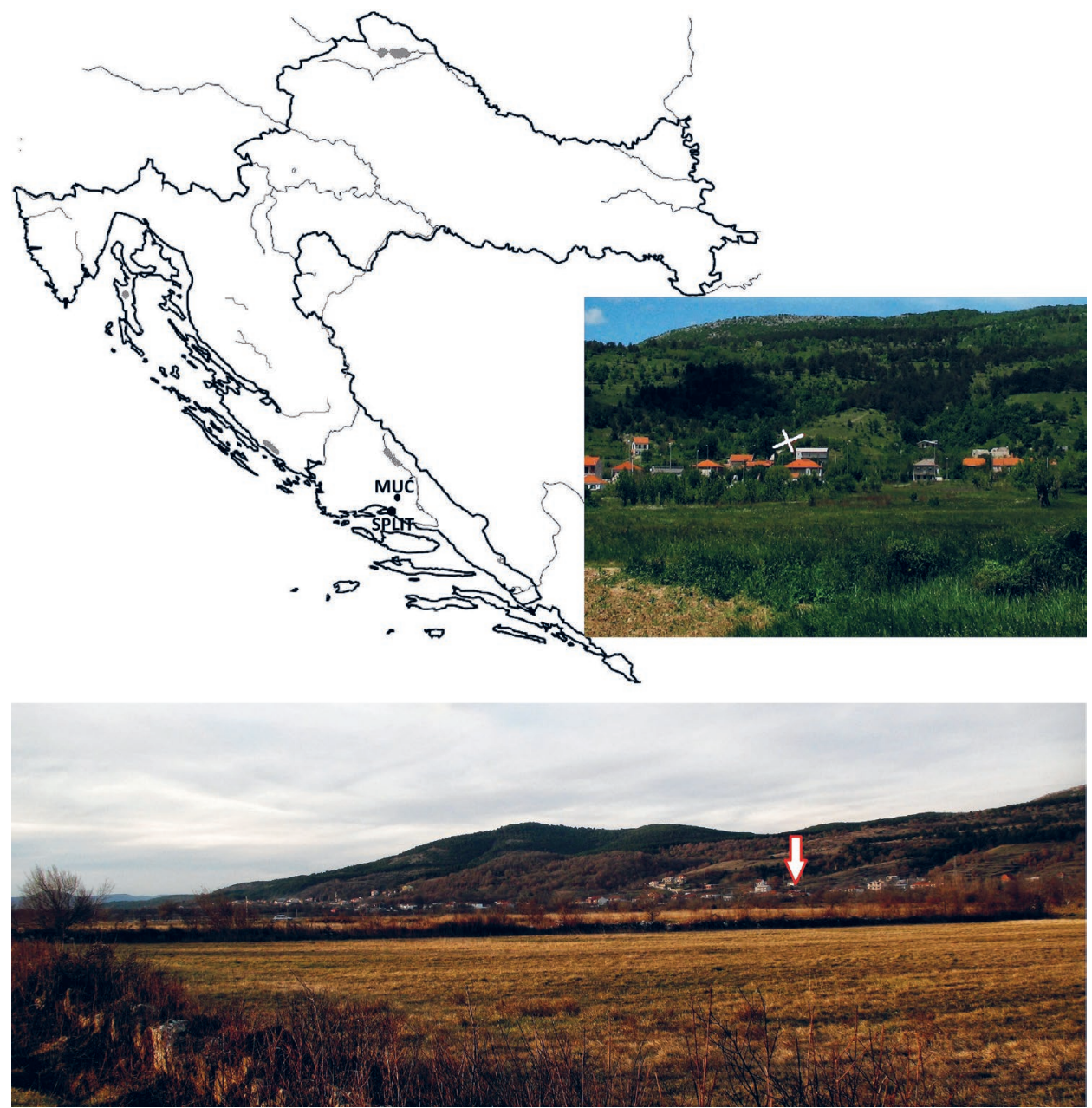

Fig. 1. Position of the locality Grudina (arrow and cross) in Gornji Muć near Split.

The cold and dry mountain air from the northeast is mitigated with moist and warmish southern winds creating the sub-Mediterranean climate vegetation zone with dominant Quercus pubescens communities. Irregular winter temperature fluctuations bring periods of cold days below zero degrees Celsius, versus short warm periods when insects are active (personal observation B. Kokan). To the south the collecting place was close to the fields and slopes planted with vineyards and orchards and to the north it was open to a small wood and pasture.

The Malaise trap used was a slightly modified Townes type (with only a higher and broader "roof"). The collecting head was made of a plastic bottle with an opening drilled in its upper part from which a short passage-tunnel connected the trap with the collecting bottle. The connection of the trap 
with the collecting bottle was made according to the utility model "Insect trap" No. 20571 (Industrial Property Office of the Czech Republic): the polyester fabric of the upper part of the trap was fixed between the middle and the outer of the three concentric cylinders made of small PET bottles; the entire passage-tunnel was fixed to collecting bottle with string. The collecting bottle was filled with 2 litres of $1 \%$ formalin solution, with liquid soap added to reduce surface tension (Fig. 2).
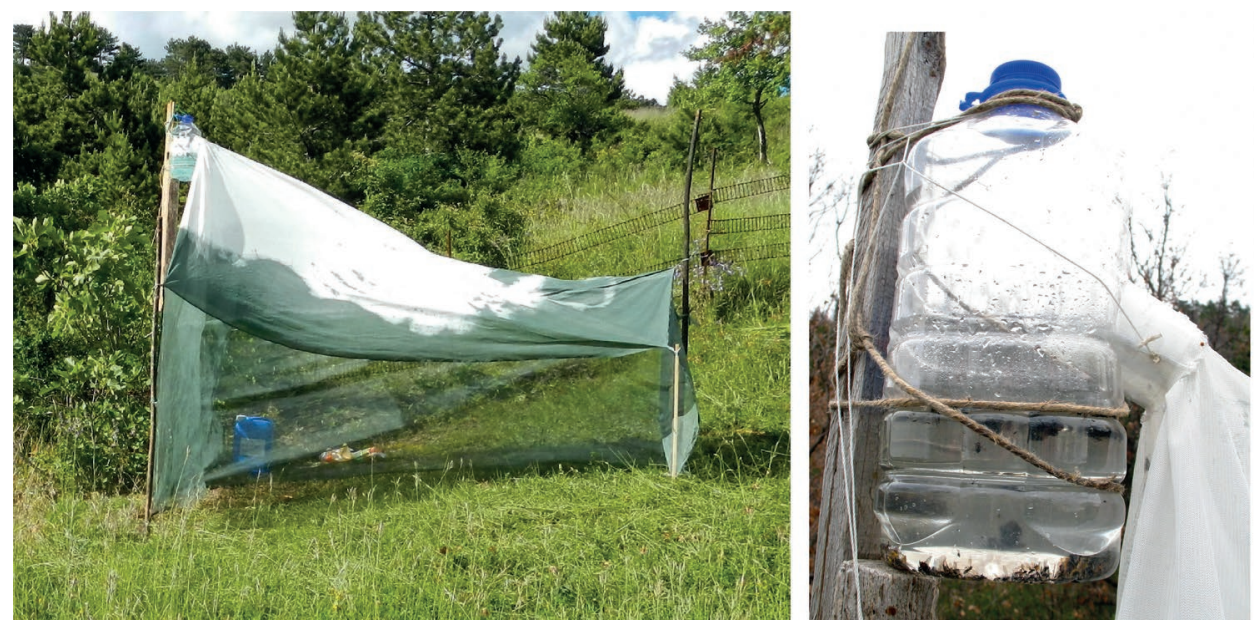

Fig. 2. The Malaise trap with collecting head on Grudina hill.

The collecting bottle was emptied every two to three weeks over one period in 2013 (from 27 May to 6 December) and another in 2014 (from 27 April to 10 December) with the goal of estimating the local fauna of flying insects, mainly Diptera. The specimens from each sample were collected from the collecting bottle by means of a fine tea strainer and placed in storage bottles containing $70 \%$ ethyl alcohol and they were kept in a refrigerator.

Dipterans were sorted by means of the morphospecies method and voucher specimens were dried and mounted by the method described by BАRтÁк (1997). The authors have presented here only a fragment of first author's original but yet unpublished key of the huge Rhamphomyia genus and Pararhamphmiya subgenus.

The collected specimens of Rhamphomyia intersita will be kept in the collection of the Czech University of Life Sciences in Prague and in the Entomology Collection of the Natural History Museum and Zoo Split.

\section{RESULTS AND DISCUSSION}

The first finding of Rhamphomyia intersita in Croatia and in Europe (Fig. 3) was recorded. The Malaise trap sample from 10/10/2014 to 216/10/2014, revealed 3 female specimens of $R$. intersita. The sample from $26 / 10 / 2014$ to $23 / 11 / 2014$ contained a single female of the species and in the sample from 23/11/2014 to $10 / 12 / 2014$ a single female of $R$. intersita was found again. This species belongs to the genus Rhamphomyia and to its subgenus Pararhamphomyia. The original key of the species group of Pararhamphomyia is presented to make it easier to separate $R$. intersita from other similar species of the subgenus.

Key to the Palaearctic species of Rhamphomyia (Pararhamphomyia) with black legs, multiserial dorsocentrals and an at least partly pale setose body

1 All mesonotal setae and setulae pale or mesoscutum polished to subpolished

- At least a few setulae dark, mostly both acrostichals and dorsocentrals dark. Mesoscutum grey microtrichose 
2 (1) Halter black. Male hypopygium very small, smaller than tip of abdomen. Hind femur without setae ventrally, only with "pilosity". Female fore femur dorsally near base, middle and hind femur and all tibiae at least above pennate lucidula Zetterstedt

- Halter yellow or male genitalia large. Remaining characters different 3

3 (2) At least disc of mesoscutum lustrous, lacking microtrichiae tenuiterfilata Becker

- Mesoscutum microtrichose to subpolished. 4

4 Male 5

- Female . 9

5 (4) Hind legs strongly deformed merzi Barták

- Hind legs not deformed

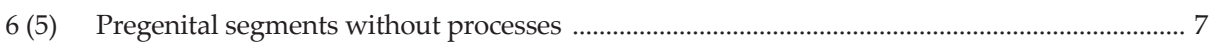

- Pregenital segments with processes . 8

7 (6) Cercus globular. Epandrium simple, without tuft of setae

physoprocta Frey

- Cercus not globular. Epandrium elongated, with very long apical setae and a submedial tuft of yellow setae chimganensis Barták

8 (6) Phallus forms a fold in middle. Mid tibia with a few very long setae dorsally including preapicals. Fore basitarsus thicker than tip of tibia subsultans Frey

- Phallus without any fold in middle, forming simple loop. Mid tibia with short setae dorsally at most twice as long as tibia is thick, preapicals short. Fore basitarsus narrower than tip of tibia tienshanensis Barták

C9 (4) Wings brown. (Additional character: 4 scutellars) tienshanensis Barták

- Wings clear 10

10 (9) 6 scutellars. (Additional characters: larger species, body length over $3.5 \mathrm{~mm}$, abdominal tergites 6-8 polished, propleuron bare, costal seta absent) subsultans Frey

- 2-4 scutellars 11

11 (10) Wings milky white. Propleuron bare physoprocta Frey

- Wing not milky white. Propleuron setulose merzi Barták

12 (1) First abdominal sternite setulose. Male phallus rather thick. (Additional characters: face very narrow, about as front ocellus. Female legs not pennate.) angustifacies Saigusa

- First abdominal sternite bare. Male phallus thin, hair like 13

13 (12) Male: $8^{\text {th }}$ syntergosternite lustrous, armed with processes. (If mesoscutum lustrous, compare R. lucidula). Female: middle and hind femora virtually bare anteroventrally, hind femur with short posteroventral pennation on apical $2 / 3$, abdomen light grey microtrichose, $8^{\text {th }}$ segment contrastingly lustrous, hind tibia not pennate pilimanicula Saigusa

- Both male and female characters different 14

14 (13) Male: cercus much broader than epandrium. Female: hind femora and tibiae with short pennate ciliation fascipennis Zetterstedt

- Male: cercus narrower than epandrium. Female legs not pennate. 15

15 (14) Palpus yellow. Six or more scutellars. Male: legs long haired, especially all basitarsi long setose dorsally (some setae are almost as long as basitarsi); abdomen silvery grey. Female: wing light brownish, discal medial cell elongated, longer than vein $\mathrm{M}_{2}$ intersita Collin - Palpi black. 2-4 scutellars. Other characters in another combination. 16 


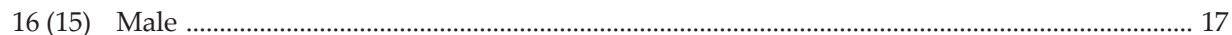

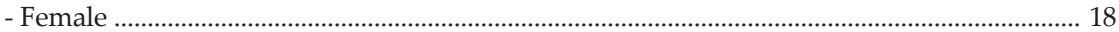

17 (16) Wings milky white, veins $R_{2+3}$ and $R_{4+5}$ pale. Mesoscutum light bluish grey. Fore tibia with short posterodorsal ciliation. Epandrium with dense submedial tuft of yellow setae. Halter yellow. $8^{\text {th }}$ sternite long niveipennis Zetterstedt

- Wings not milky white, veins $R_{2+3}$ and $R_{4+5}$ brown. Mesoscutum dark brownish grey. Fore tibia with posterodorsal ciliation longer than diameter of tibia. Epandrium with only a few submedial setae. Halter brownish yellow. $8^{\text {th }}$ sternite short dispar Zetterstedt

18 (16) Wings clear. Halter pale yellow niveipennis Zetterstedt

- Wings at least partly brown at least apically. Halter yellow or darkened. dispar Zetterstedt

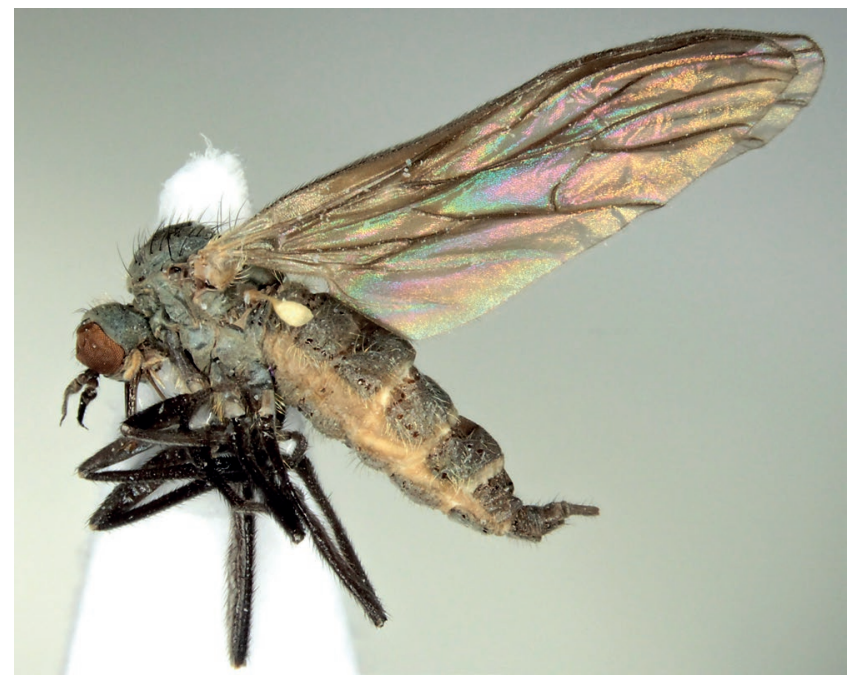

Fig. 3. Female of Rhamphomyia intersita from Gornji Muć in Croatia.

\section{ACKNOWLEDGEMENTS}

This paper was supported by an S grant of MSMT (Ministry of Education, Sports and Youth, Czech Republic). Our special thanks are due to the anonymous reviewers and Josip Skejo BSc for improving the manuscript.

Received October 5, 2017

\section{REFERENCES}

BARTÁk, M., 1982: The Czechoslovak species of Rhamphomyia (Diptera, Empididae), with description of a new species from Central Europe. Acta Universitatis Carolinae - Biologica 1980 (1982), 381-461.

BARTÁK, M., 1997: The biomonitoring of Diptera by means of yellow pan water traps. Folia facultatis scientiarum naturalium Universitatis Masarykianae brunensis, Biologia, 95, 9-16.

BARTÁK, M., 2007: Five new European species of the Rhamphomyia (s.str.) albosegmentata group (Diptera: Empididae). Revue Suisse de Zoologie 114 (2), 417-435. 
Barták, M., Çıftçı, M.C. \& Hasbenli, A., 2007: A new species of Rhamphomyia (s. str.) Meigen (Diptera, Empididae) from southern Anatolia. Entomological News 118 (2), 143-147.

BARTÁк, M. \& Kubíк, Š., 2008a: New peculiar eastern palaearctic Rhamphomyia (Diptera: Empididae). Entomological News 119 (4), 338-344.

BARTÁк, M. \& Kuвíк, Š., 2008b: A new species of Rhamphomyia (Pararhamphomyia) (Diptera: Empididae) from Thailand. Oriental Insects 42, 285-289.

BARтÁк, M. \& Kubíк, Š., 2008c: Four new West Palaearctic species of the Rhamphomyia (s.str.) (Diptera: Empididae). Revue Suisse Zool. 115 (1), 25-36.

BARTÁK, M. \& Kubíк, Š., 2009: Two new east palaearctic Rhamphomyia (Pararhamphomyia) (Diptera: Empididae). Entomological News 120 (1), 76-86.

BARтÁк, M. \& Киві́к, Š., 2010: Three new European species of the Rhamphomyia (s. str.) melania group (Diptera: Empididae). Revue Suisse se Zoologie 117 (1), 89-100.

Barták, M. \& Кивíк, Š., 2012: A review of the Palaearctic species of Rhamphomyia subgenus Holoclera (Diptera: Empididae) with description of 5 new species. Revue Suisse de Zoologie 119 (3), 385-407.

BARTÁк, M. \& Kuвíк, Š., 2015: Palaearctic species of Rhamphomyia (Pararhamphomyia) anfractuosa group (Diptera, Empididae). ZooKeys 514, 111-127.

Barták, M., Kubík, Š., Civelek, H. \& Dursun, O., 2014: New species of Rhamphomyia (Diptera: Empididae) from Turkey with a key to species of the Middle East and adjacent territories. Zootaxa 3815 (1), 68-78.

Collin, J.E., 1960: Some Empididae from Palestine. Annals and magazine of natural history Ser. 13 (2), $385-420$.

SAigusa, T., 2012: A new Asio-Nearctic subgenus of Rhamphomyia (Diptera: Empididae: Empidinae). The Canadian Entomologist 144 (2), 291-322.

YAnG, D., Zhang, K., YAO, G. \& Zhang, J., 2007: World Catalog of Empididae (Insecta: Diptera). China Agricultural University Press, Beijing 599 pp. 